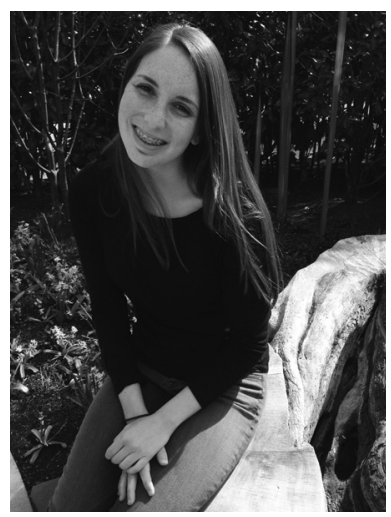

HANNAH MILSTEIN is currently pursuing a Bachelor of Arts in History and a minor in Religious Studies at Cal Poly San Luis Obispo. Her areas of historic interest include Jewish history as well as the Cold War era. Recently, she completed an internship with the San Luis Obispo Jewish Community Center aiding with their preparations for Holocaust Remembrance Day. Hannah is also a member Cal Poly's chapter of Phi Alpha Theta as well as an Ambassador for the College of Liberal Arts at Cal Poly. 


\section{IDENTITY AND THE HOLOCAUST: AMERICAN JEWRY IN THE 1950S}

Hannah Milstein

"Peter added, 'The Jews have been and always will be the chosen people!' I answered, 'Just this once, I hope they'll be chosen for something good!" This excerpt from Anne Frank's diary, written by a fifteen year old girl in Holland, somehow captures the spirit of American Jewry during the 1950s. While American Jews had finally begun to enjoy some of the benefits of American life, anti-Semitism and discrimination continued to pervade their existence. Most importantly, this quote signifies the American Jews of the postwar era were directly linked to their European counterparts through the Holocaust.

The Holocaust today is considered an integral part of defining the group identity of American Jewry. While this statement may seem concrete to the modern observer, there is heavy debate about whether this has always been the case. ${ }^{1}$ There are two major camps of thought on this subject. Many historians

\footnotetext{
${ }^{1}$ Hasia Diner, We Remember with Reverence and Love: American Jews and the Myth of Silence After the Holocaust 1945-1962(New York: New York University Press, 2009), 3. Peter Novick, The Holocaust in American Life (New York: Houghton Mifflin Company, 1999), 1. Alan Mintz, Popular Culture and the Shaping of Holocaust Memory in America (Washington: University of Washington Press, 2001), ix-x. Henry L. Feingold, Bearing Witness: How America and Its Jews Responded to the Holocaust (New York: Syracuse University Press, 1995), 3. All of these sources in some way note the importance of the Holocaust in modern Jewish identity within the first few pages of their writing and subsequently engage an opinion on the subject.
} 
champion the argument presented by Peter Novick that Jewish Americans on the whole remained silent about the Holocaust in order to become full participants in the new Postwar American prosperity; conformed and consuming, patriotic members of the democratic society with God on its side. ${ }^{2}$ In contrast is the view presented by Hasia Diner, proclaiming that Jews did in fact talk about and pursue memorials of the Holocaust frequently in the postwar period while still pursuing these American goals. ${ }^{3}$

Although both can be correct, what these two sides fail to acknowledge is the limitations that the scope of their argument creates. Novick and others like him mainly look to the greater American public and government, as well as national Jewish conversations on the Holocaust to draw their conclusions, ignoring the many local, community based conversation that construct Diner's points. What they overlook is the medium between the two sides: that their accounts can coexist and can be explained by the context in which they occurred. Conversations may have primarily taken place on the local level, but they still contributed greatly to the construction of a collective identity for American Jewry.

During the 1950s, American Jews were inherently bound together by their wariness of the specter of Hitler's Final Solution, as, even in the United States, anti-Semitism remained present in varying forms and severity. ${ }^{4}$ In some cases during the postwar period Anti- Communist and Anti-Semitic were synonymous in the way that Jew and Communist had been for those crusaders against unAmerican activity. ${ }^{5}$ On a more personal, level Jews were discriminated against in the work place and in college admissions, faulted for the "defects of their race" and praised for their disassociation with qualities deemed inherently Jewish. ${ }^{6}$ Those national sentiments against Jews coupled with the pressure to reevaluate

\footnotetext{
${ }^{2}$ Peter Novick, The Holocaust in American Life. Alan Mintz, Popular Culture. Henry L. Feingold, Bearing Witness. Also Jenna Weissman Joselit, The Wonders of America: Rienventing Jewish Culture 1880-1950 supports the idea of Jews embracing American culture and consumerism during the postwar period.

${ }^{3}$ Hasia Diner, We Remember, 14.

${ }^{4}$ Diner, We Remember, 300.

${ }^{5}$ Clancy Sigal, "Hollywood During the Great Fear", Present Tense 9 (1982), 45-48. Diner, We Remember, 287. While there were Jewish anti-Communists many believed that at least during the McCarthy era there was an element of anti-Semitism that was closely associated with anti-Communism.

${ }^{6}$ Andrew S. Winston. "'The defects of his race': E.G Boring and Anti-Semitism in American Psychology, 1923-1953,” History of Psychology 1 (February 1998), 28.
} 
Germany in light of the new Cold War geopolitics created an atmosphere in which American Jewry was caught between their duties as Americans and Jews; believing it was necessary to remember the Holocaust, but not comfortable enough to differentiate themselves as a minority on the National stage. This conflict would not only lead to a crisis of identity for American Jewry but create a climate in which an integral part of that identity, the Holocaust, would only be acknowledged among other Jews.

To understand this phenomenon it is imperative to examine the popular media of the postwar period, and the fact that during this time, few non-Jewish media outlets covered the results of the Holocaust. While searching through popular outlets like Life magazine, as well as The New York Times and Los Angeles Times, articles about the Holocaust are hard to find. Much of the coverage by major newspapers is only a brief mention of the horrors of the Holocaust in conjuncture to the creation of the state of Israel. The articles rarely probed into the question of why the Holocaust happened; it was merely a detail to justify the creation of Israel, a state that held some political purpose for the U.S. in the Cold War. ${ }^{7}$ Life magazine also reflected this trend with only two pieces covering the Holocaust between August 1945 and December 1960. One piece about the Warsaw Uprising not only downplayed the role of Jews in the event but its main purpose was to prove that the Cold War was a Russian production started in the midst of WWII; the other an advertisement for the Destiny Campaign by the United Jewish Appeal, selling the idea of Israel to the American population as a humanitarian effort. ${ }^{8}$ The latter, produced in 1948, does little to educate its readers on the Holocaust, only taking one line to describe the Jews already and planning to live there as deserving, hard-working peoples who have "shown their caliber" and "emerged from the Holocaust and mass murder of the last ten years with an indomitable will to live and with an overpowering eagerness to be productive". 'This description downplays the Holocaust and in part the Jewishness of these inhabitants of Israel in an effort to relate them to the average American through the American values of hard work and ingenuity. This

${ }^{7}$ Peter Novick, The Holocaust, 110. "Letters to the Times: Bevin Statement is Debated", The New York Times, November 20, 1945, 20. "Proclamation of a New Jewish State", The New York Times, May 15, 1948, 2.

${ }^{8}$ Henry Morgenthau, Jr., "History has privileged us," Life, March 22, 1948, 145. Sir Winston Churchill, "Triumph and Tragedy: Russian failure to help the Warsaw patriots and fruitless talk about the Polish government revealed the Cold War was already on" Life, November 2, 1953, 54.

${ }^{9}$ Morgenthau, Jr., "History has privileged us", 145. 
was a fresh start for the Jewish image in postwar America and one in which the Holocaust did not fit into the mainstream, non-Jewish media, even with regards to the Jewish state of Israel.

All of these examples were geared to non-Jewish Americans and were minimal at best, but the nature and coverage of the Holocaust in America changed drastically with the English publication of The Diary of Anne Frank in 1952. The diary has been revered as a turning point in Holocaust awareness. According to Historian Alan Mintz, it "create[ed] a bridge of empathetic connection, even identification, between the fate of European Jewry and ordinary American readers who had no ethnic or religious link to the victims". ${ }^{10}$ While this publication brought higher visibility to the Holocaust than ever before, its cultural advancement was imposed on by the belief of many historians that the text was edited to downplay Anne's Judaism. ${ }^{11}$ Mintz is careful to note the edits done by Anne's father to the original diary's publication and the later editing done for the stage version by Albert Hackett and Frances Goodrich are careful to present Anne in the most flattering way to a Gentile audience. This meant editing out accounts of her budding sexuality as well as making her Jewishness seem "inessential" as her "identity is folded into the generality of victims of fascism and even into the larger class of the unjust world". ${ }^{12}$

Another historian argues that while this grouping of Anne with other victims of fascism may also occur, it is Anne's perspective as a child that "muted her Jewishness from the very beginning". Like others, he stresses the fact that American non-Jewish audiences would not have connected with a blatantly Jewish character, therefore, it was because she was a child that "even latently anti-Semitic American audiences of the 1950s welcomed her into their hearts". ${ }^{13}$ All of these theories culminate in a New York Times book review of the diary in 1959. With the rerelease of her works, along with new short stories and sketches, the reporter Charles Poore does not once mention that Anne is Jewish, instead he describes her as "one of the great tragic figures of our century" and "the conscious of a ruthless era" linking her plight to those of the victims of fascism,

${ }^{10}$ Alan Mintz, Popular Culture and the Shaping of Holocaust Memory in America (Washington: University of Washington Press), 18.

${ }^{11}$ Alan Mintz, Popular Culture, 19-20. Peter Novick, The Holocaust in American Life. Mark M. Anderson, "The Child Victim as Witness to the Holocaust: An American Story?", Jewish Social Studies 14, (2007), 1-6.

${ }^{12}$ Alan Mintz, Popular Culture, 19-20.

${ }^{13}$ Mark M. Anderson, "The Child Victim as Witness," 3-4. 
not the singular fate of Europe's Jews. Her ethnic identity downplayed, Poore spends most of the article describing her as a child, a naïve window onto a cruel and quickly changing world. ${ }^{14}$ It is trends like this, directly in the postwar era that demotes The Diary of Anne Frank from the pinnacle of Holocaust remembrance to a mere whisper of the event, further proving that Jews and Jewish themes did not fit comfortably into the American cultural landscape.

With all of these examples of popular media coverage it is important to note which sources were actually covering the Holocaust related issues during the postwar period. The trend that surfaces is that these were commonly Jewish sources geared towards Jewish readers, a project spearheaded by the American Jewish Committee with its two most influential publications, The Jewish American Yearbook and the magazine Commentary. Commentary is probably the most prevalent, as throughout the postwar period they produced a variety of articles for the academic Jewish audience on subjects relating to the Holocaust and status of Jews in the United States. Within this forum of Jewish thought, mostly Jewish authors were able to express their thoughts and research, opinions and feelings, about the greatest catastrophe to ever affect modern Judaism. They were able to lament their losses and look to the future, all while crafting the Holocaust as a distinct part of their experience as American Jews. In their articles, Jews were able to confront the horrors of the death camps and the uniquely Jewish aspect of the Holocaust that mainstream media seemed unable to do. ${ }^{15}$ They also approached the question of who was to blame for this travesty, knowing full well that it was the pervasiveness of the world that allowed the Holocaust to continue as it did. ${ }^{16}$ Although there are reports on the actual events of the Holocaust, the bulk of Commentary's discussion on the Holocaust during the postwar period is interwoven with pieces on antiSemitism, presenting a type of constant vigilance and wariness of their Gentile neighbors. ${ }^{17}$ The Jews of the postwar period, to an even greater extent than their predecessors, were aware that they lived in a predominately Christian world and one that recently had, and could easily again, turn hostile towards them.

${ }^{14}$ Charles Poore, “Books of The Times,” The New York Times, September 22, 1959.

${ }^{15}$ Arther Settel, “Seven Nazis Were Hanged” Commentary, 29 (1960) 369.

${ }^{16}$ L, Poliakov "The Vatican and the Jewish Question", Commentary, 10 (1950), 439. H. R. Trevor-Roper, "Is Hitler Really Dead?", Commentary, 11 (1951), 120

${ }^{17}$ Leo S. Baeck., "The Task of Being an American Jew", Commentary, 11 (March 1951) 217. David Riesman, , “The Militant Fight Against Anti-Semitism”, Commentary, 11 (1951) 11 
These were the feelings characterized by Commentary, as well as the American Jewish Yearbook, which encountered many of the same themes as Commentary but presented these issues of the Holocaust and the Jewish experience in report, rather than article, format.

While those two were some of the larger Jewish publications engaging the Holocaust at the time, there are countless examples of sermons, essays, and prayers written just for local Jewish communities and their memorialization of the Holocaust. One example is the "Seder Ritual of Remembrance: For the Six Million Who Perished at the Hands of the Nazis and for the Heroes of the Ghetto Uprisings" published by the American Jewish Congress in 1952 for "a broad usage in American Jewish homes, schools, and community settings". ${ }^{18}$ It is an interesting but strategic move to place a ritual of remembrance with the holiday of Passover. The story of Passover and the enslavement of Jews by the Egyptians is one that is deeply important to the Jewish faith and identity. Practically every practicing Jew celebrates at least some version of the holiday, and it is safe to assume that culturally and religiously Passover is a part of the Jewish identity. This pairing is significant in many ways, but mainly because as early as 1952, it shows an effort on American Jewry's part to never forget the Holocaust and intertwine it with similar themes already existing in the Jewish identity. This type of remembrance was just one of many as "specially designed books and cemetery markers, invocations at meetings, and book dedications" provided American Jews with the tools to memorialize the Holocaust. ${ }^{19}$

Another example of more localized Jewish memorialization comes in the form of an the form of an excerpt from an essay produced by a young Jewish camper Sharon Feinman at the Reform movement's Camp Institute in 1956. The essay, while bearing the markings of a young perspective, fully engages the tragedy and pain caused by the Holocaust, but once again it is an example found deep within the confines of the Jewish community. ${ }^{20}$ Going to Jewish camp for Jewish children and teenagers is almost a universal experience, and for years has been a place for those youngsters to build their own budding Jewish identities and communities. What this and other mediums of memory like it have in common is the fact that they are directly linked to conversations within local Jewish communities. While some may have been published by larger national

\footnotetext{
${ }^{18}$ Hasia Diner, We Remember 2 19. Photocopy of actual document in book.

${ }^{19}$ Hasia Diner, We Remember, 50-51. Another photocopy of a memorial service flyer.

${ }^{20}$ Hasia Diner, We Remember 21.
} 
bodies they were meant as tools for conversation at the most commonplace level of Jewish culture, the synagogue or community. The language of these memorials or even the setting of them does not promote non-Jewish participation; in fact it encompasses the conversation it encourages to only Jewish circles.

Looking at the conversations of the Holocaust in the national media only depicts a trend: that Jews, and Non-Jews did not engage in a conversation about the Holocaust, while Jews were eager to memorialize it among themselves during the postwar period. To understand this trend it is important to examine the atmosphere of the 1950s and its relationship to American Jews. Many historians state that the 1950s was a time of declining anti-Semitism as Jews were embraced by the suburbanized, consumerist, American society. ${ }^{21}$ While Jews did begin to enjoy American life in ways that they had never before had been able to, anti-Semitism in the United States was far from in its decline. In fact, anti-Semitism, while "latent" compared to that experienced before and after the war in Europe, still thrived within the United States. ${ }^{22}$

This experience of anti-Semitism for postwar Jews can be divided into two major categories: discrimination and violence. The United States has had a long history with both of these but the best documented is discrimination. From the quotas on immigration and college admissions, to the refusal to hire based on religion American Jewry was not new to discrimination in the U.S. For the year of 1950 the American Jewish Yearbook dedicated most of their "Civic and Political" section to discussing the issue of discrimination against Jews in the United States. Jews received treatment similar to other minorities at the time; meaning they experienced things such as housing bias in which they were among a list of "undesirables" and therefore not given the opportunity to rent or purchase homes in certain neighborhoods. ${ }^{23}$ Jews were also discriminated against in the workplace as the American Jewish Yearbook reported that "Ninety-five per cent of the private employment agencies reported that Jewish applicants faced serious discriminatory barriers in attempting to qualify for jobs" and many agencies did not even list them for qualified jobs. ${ }^{24}$ At this point in time this

\footnotetext{
${ }^{21}$ Peter Novick, The Holocaust in American Life. Alan Mintz, Popular Culture. Henry L. Feingold, Bearing Witness.

${ }^{22}$ Mark M. Anderson, "The Child Victim as Witness," 6. American Jewish Committee, "Civic and Politics", American Jewish Yearbook 51 (1950), 99.

${ }^{23}$ AJC, "Civic and Politics", American Jewish Yearbook 51 (1950), 3-4.

${ }^{24}$ AJC, "Civic and Politics", American Jewish Yearbook 51 (1950), 99.
} 
type of discrimination was still legal creating an unwelcome atmosphere for American Jews. This theme continued as many prestigious private universities instituted quotas on Jewish students as late as $1960 . .^{25}$ This discrimination not only barred Jews from reaching the upper echelons of academic achievement at the time, but represented American hostility to Jews gaining the status that came with those degrees. An Ivy League degree represented more than just an education, it was a level of society that, thanks to the quota system's discrimination, left Jews unwelcome.

This discrimination itself would motivate many Jews during the post war era to attempt to not single themselves out among the general American population. If keeping the conversation of the Holocaust within the community meant avoiding certain distinctions that would lead to discrimination, then many Jews saw it in their best interest to keep it that way. These feelings were only compounded when American Jewry was faced with the most dangerous product of anti-Semitism: violence. During the postwar period "there was a greater tendency of individual [anti-Semitic] agitators to combine operations, as well as increasing stress on the distribution of inflammatory literature as the principal form of overt activity" according to the Jewish American Yearbook as they also noted that "the principal theme exploited by anti-Semitic agitators was the identification of Jews as Communists and as conspirators for world control" a sentiment that had greatly increased since the end of the second World War. ${ }^{26}$ The report dedicated six pages to the subject of "Anti-Jewish Agitation" breaking it down into groups of various themes from the Klu Klux Klan, to mother's and patriot groups. While the majority of these groups and individuals mentioned were mostly dedicated to anti-Semitic propaganda and rallies some did cross the line into violence. ${ }^{27}$ Throughout the post war period there were multiple incidents of attempted and successful synagogue bombings and assaults on Jewish communities. In the Midwest and South, Jews were targeted by these groups and alienated by treatment that paralleled some events leading up to the Holocaust in Germany. ${ }^{28}$ This treatment could only

${ }^{25}$ Lawrence Bloomgarden, “Our Changing Elite Colleges,” Commentary, 20 (1960), 162.

${ }^{26}$ AJC, "Civic and Politics", American Jewish Yearbook 51 (1950), 110.

${ }^{27}$ AJC, "Civic and Politics", American Jewish Yearbook 51 (1950), 110-115.

28 "Boy Admits Synagogue Bombing in Alabama: Self-Styled Nazi, 16, Charged With Two Counts of Assault With Intent to Murder”, Los Angeles Times, March 27, 1960, 4. Emanuel Perlmutter, "HOGAN CALLS U. S. LAX OH BOMBINGS: Derides Keating's Promise to See if Laws Are Needed in Synagogue Attacks", The New York Times, October 16, 1958, 23. "Negroes and Jews Targets of Bombings", Los Angeles Times, Apr 29, 1958, 20. 
create an atmosphere in which Jews would feel uncomfortable talking about the Holocaust, in a way that would further differentiate them and call attention to potential tormentors.

As anti-Semites in the U.S. took cues from their Nazi predecessors, American Jewry was actively keeping an eye on their location of inspiration: Germany. During the late 1940s and early 1950s American Jews were particularly concerned with the state of Germany and were conflicted with its treatment by the United States. ${ }^{29}$ As the Cold War began to take shape the image of Germany was rehabilitated in the U.S. in a way that Jews found hard to reconcile. ${ }^{30}$ A country that had been an enemy only five or so years before was now an important ally of the United States in their geopolitical fight against the Soviet Union. Unlike the rest of the country, American Jewry did not forget quickly the horrors of WWII and the vital role that Germany had played in them. And while they supported the United States, most Jews were not ready to economically or politically support a state which still housed many supporters of Hitler. ${ }^{31}$

In magazines like Commentary throughout the postwar period there was a particular focus and concern on the state of Germany and the anti-Semitism still prominent in their society. One particular example from Commentary is the article "The Aftermath of Nazi Rule: A Report from Germany" by Hannah Arendt. Written in 1950, it spends most of its length describing the state of the German people. Careful to remain unbiased, the author slips at certain points and ultimately reveals some of the undercurrents of Jewish-American opinion. She notes that one of "the most striking and frightening aspect" was what she believed was a "German flight from reality" and a "habit of treating facts as though they were mere opinions" in regards to the horrors of the Holocaust and the state of anti-Semitism in their country currently. Her choice of language depicts a sense of frustration, wariness, but most importantly blame as it becomes apparent that "reality" puts the guilt of these horrors on the German people. Throughout the pieces written there are echoes of fear for the past and a wariness of the future, but the sentiment that the Holocaust and most of the horrors of WWII were a direct consequence of German actions remains concrete. This pervasive opinion among America's Jews did not fit the mold

\footnotetext{
${ }^{29}$ Milton Himmelfarb, "In the Community: Swastikas, Resolution, Scholarship," Commentary, April 1960.

${ }^{30}$ Hasia Diner, We Remember, 216

${ }^{31}$ Hasia Diner, We Remember, 218. Interview with Leah "Bubbe" Ezray, November 11, 2012.
} 
of a patriotic American during the Cold War and created a crisis of identity as Jews strove to be American yet could not forgive their nation's new ally of its past actions. This dichotomy led to the suppression of talks about the Holocaust to just within the confines of the Jewish community, as Jews avoided being further singled out by not conforming to this aspect of American life.

This conflict of interest is what characterized the experience of American Jewry. Whether to be Jewish or American, to face discrimination but retain their ancient cultural heritage and belief system or to assimilate and forget events of the past? The Holocaust epitomized this struggle; Europe's Jews had refused to, or not even been given a choice to assimilate and had therefore been eradicated by racist ideology. Despite the fact that these horrific events transpired far from the homes of American Jews, in a country and continent that many had never been to, they realized that it was merely luck of geography that separated them and Europe's Jews from the same fate. ${ }^{32}$ This knowledge and understanding of the society in which they lived revealed itself in a pervading skepticism of American society by Jews who warily embraced it during this period.

Yet despite discrimination, violence and a heavy undercurrent of fear, Jews still continued to memorialize the Holocaust in their communities. In the end this is the key to a conclusion about Jewish identity in the 1950s, this continued persistence to memorialize the Holocaust within Jewish communities as one sociologist describes it was a "paradox of persistence through (not despite) persecution". This theory labels persecution as "simultaneously timeless, dreaded, and expected" within Jewish culture. ${ }^{33}$ This seems to hold true while examining such cultural staples as Hanukkah and Passover; both center on the destruction of Jewish culture by a despotic foreign power. The Holocaust fits in with these religious stories as merely the most recent and cataclysmic of what constituted an ancient history of Jewish persecution. As American Jews experienced anti-Semitism within the U.S., or at least alienation to some degree, the idea that the Holocaust was an "imminent...danger", a lesson to not be forgotten, became evident as a staple of the Jewish experience. ${ }^{34}$ Yet this certainty to remember was accompanied by a wariness that would come

\footnotetext{
${ }^{32}$ Novick, The Holocaust in American Life, 76.

${ }^{33}$ Howard F. Stein, "The Holocaust, the Uncanny, and the Jewish Sense of History," Political Psychology, 5 (1984), 5.

${ }^{34}$ Stein, "The Holocaust, the Uncanny," 5.
} 
to characterize all Jews of the postwar period: a group willing to embrace their new culture yet unable to trust it at the same time.

During the postwar period the Holocaust encompassed all Jewry with its tragedy and repercussions leaving remaining witnesses affected and changed forever. In her diary, Anne recalls the Jews as a "chosen people" but never chosen for anything good. This mixed definition as a unique, even special, group but one characterized by persecution is exactly how American Jews saw themselves; conflicted by their past abroad as well as their more imminent future in the U.S. This identity of conflict was heavily influenced by the cultural context in which it persisted. While the directly perceived conflict of being American versus Jewish would eventually subside and allow for national conversations of the Holocaust, it would take the coming of the 1960s and a change in cultural and political context for the Holocaust to develop into an American issue, not just a Jewish one. ${ }^{35}$ Yet regardless of this public transformation the Holocaust, and what remains of that wariness of the 1950s, continues to be a vital part of the American Jewish experience as Jews continue on in a "paradox of persistence".

\footnotetext{
${ }^{35}$ Novick, Mintz, and Diner all note the 1960s as a changing point in Holocaust perception in the United States for either political or cultural reasons.
} 


\section{BIBLIOGRAPHY}

American Jewish Committee. "Civic and Politics." American Jewish Yearbook, 1950.

Anderson, Mark M. "The Child Victim as Witness to the Holocaust: An American Story?,” Jewish Social Studies 14, (2007), 1-6.

Baeck, Leo S. "The Task of Being an American Jew," Commentary, March, 1951.

Bloomgarden, Lawrence ."Our Changing Elite Colleges," Commentary, February 1960.

Churchill, Sir Winston. "Triumph and Tragedy: Russian failure to help the Warsaw patriots and fruitless talk about the Polish government revealed the Cold War was already on." Life, November 2, 1953.

Diner, Hasia R. We Remember with Reverence and Love: American Jews and the Myth of Silence after the Holocaust 1945-1962. New York: New York University Press, 2009.

Feingold, Henry L. Bearing Witness: How America and Its Jews Responded to the Holocaust. New York: Syracuse University Press, 1995.

Himmelfarb, Milton. "In the Community: Swastikas, Resolution, Scholarship," Commentary, April 1960.

Interview with Leah "Bubbe" Ezray, November 11, 2012.

Mintz, Alan. Popular Culture and the Shaping of Holocaust Memory in America. University of Washington Press, 2001.

Morgenthau, Henry Jr. "History has privileged us." Life, March 22, 1948.

Novick, Peter. The Holocaust in American Life. New York: Houghton Mifflin Company, 1999.

Jenna Weissman Joselit, The Wonders of America: Rienventing Jewish Culture 1880-1950

Perlmutter, Emanuel. "HOGAN CALLS U. S. LAX OH BOMBINGS: Derides Keating's Promise to See if Laws Are Needed in Synagogue Attacks," The New York Times, October 16, 1958. 
Poliakov, L."The Vatican and the Jewish Question,” Commentary, 1950.

Poore, Charles. "Books of The Times," The New York Times, September 22, 1959.

Riesman, David.“The Militant Fight Against Anti-Semitism,” Commentary, 1951.

Settel, Arthur."Seven Nazis Were Hanged,” Commentary, May 1960 .

Sigal, Clancy. "Hollywood During the Great Fear.” Present Tense 9 (1982), 45-48.

Stein, Howard F. "The Holocaust, the Uncanny, and the Jewish Sense of History," Political Psychology, 5 (1984), 5.

Trevor-Roper, H. R. “Is Hitler Really Dead?,” Commentary, 1951.

Winston, Andrew S. "'The defects of his race': E. G. Boring and antisemitism in American psychology, 1923-1953." History Of Psychology. Vol.1, no. 1 (February 1998): $27-$ 51. PsycARTICLES, EBSCOhost (accessed October 9, 2012).

"Boy Admits Synagogue Bombing in Alabama: Self-Styled Nazi, 16, Charged With Two Counts of Assault With Intent to Murder," Los Angeles Times, March 27, 1960.

“Negroes and Jews Targets of Bombings,” Los Angeles Times, April 29, 1958. 